\title{
Texts, Authority, and Community in the South African 'Ibandla lamaNazaretha' (Church of the Nazaretha), 1910-1976
}

\author{
Joel Cabrita \\ Trinity College, Cambridge, CB2 1TQ, UK \\ jmc67@cam.ac.uk
}

\begin{abstract}
This six-decade history of textual production in the Nazaretha church seeks to illuminate the changing practices of governance and community in the church during this period. The church's documentary history provides insight into its leaders' efforts to use texts to govern, centralize and discipline their geographically far-flung, often unruly congregations. In addition to focusing on the documentary regime instituted by the church's leaders, this article also explores the reading and writing practices that animated ordinary believers. For laity, as well as for leaders, texts and a general range of literate practices were a means of knitting themselves together in opposition to the incursion of the state, and in distinction to contemporary rival Christians. Finally, this article also seeks to position the texts of Nazaretha leaders and laity as significant material objects in their own right.
\end{abstract}

\section{Keywords}

Church of the Nazaretha, literacy, texts, community

Creating texts has been a key activity of the South African Nazaretha church over the past one hundred years. Petros Dhlomo, the archivist of the Nazaretha church in the 1940s until his death in the 1990s, wrote down much of the teachings of the leaders of the church — the Shembe family dynasty—as well as preserving in written form his own and believers' memories of them. One such text produced by Dhlomo is an undated parable delivered by the founder of the church, Isaiah Shembe, probably from the 1930s. In Dhlomo's record of the parable, Isaiah affirms the value of writing and alludes to the capacity of texts to create and shape human communities. Dhlomo titles Isaiah's address to the congregation at Ekuphakameni, the Nazaretha headquarters, as the 'Parable of the Book': 
You are a book, not written in ink, but with diamonds that cannot be erased and is read by all people. It is not written on flat stones. Rather, it is written in your hearts. When the people of the system will come and take these books from which the children at Ekuphakameni are singing, they will say, 'You see, all that Shembe was preaching has come to an end'. Then even a child of Ekuphakameni can say, 'We greet you at Kuphakama, We greet you Judia (Hymn 6)'. These things that were spoken at Ekuphakameni are written in the hearts of the people who love God. (Malachi $4: 2-3)^{2}$

In Dhlomo's text Isaiah speaks of the threat of the European state, the 'people of the system', destroying the church's texts and in particular the body of hymns that were circulating in both oral and written form by the mid1920s - 'the books from which the children at Ekuphakameni are singing'. Yet Isaiah affirms that if this were to happen, the true book of the church would be the Nazaretha community itself. The power of the written word can conjure up communities of people as enduring records; Isaiah tells the congregation at Ekuphakameni that a virtuous Nazaretha life is itself a written record for posterity. Isaiah presents Nazaretha lives as an enduring text written in 'diamonds', not written on a physical surface but 'in your hearts'. Dhlomo's text suggests that Nazaretha writing creates a group of people connected by the common inscription of Isaiah's words on their hearts. Both Isaiah's spoken words and Dhlomo's recording of the parable affirm the power of writing to create enduring memory. This presents writing not only as a rational technology of pen and paper, but ultimately as a spiritual inscription 'in the hearts of the people who love God'. Writing, then, for both Isaiah Shembe and Dhlomo as archivist, proclaims the power of texts to generate cohesive communities that are able to withstand the incursion of the state.

The significance of texts has undergone significant changes during the church's history. This article offers the beginnings of a history of textual production and reception within the twentieth-century Nazaretha church. The church's founder, the formally unschooled preacher and prophet Isaiah Shembe, moved to the Natal coast in about 1910. He began to accumulate a small band of followers whom he dubbed at some point 'amaNazaretha' - the Nazaretha. By 1914 Isaiah had managed to buy a 40-acre piece of land north of Durban. Here he founded the Nazaretha ritual centre, Ekuphakamenithe 'Elevated Place'. ${ }^{3}$ The Nazaretha community of Isaiah's day was largely rural, uneducated, and espoused a strongly traditionalist stance. Isaiah had an uneasy relationship with the dominant Zulu Christian social grouping of the day, the educated, Westernized amakholwa (believers) elite who prolifically produced books, newspapers, and pamphlets through mechanized printing presses, and who looked down on the largely uneducated body of Nazaretha converts. Although not part of this literate elite, Isaiah and his network of 
scribes created a highly collaborative textual culture, infused with notions of texts as miraculous, semimagical objects. Their handwritten texts often drew on a spoken idiom, capitalizing on the power of the written page as a direct spoken word. After Isaiah's death in 1935, his educated son and successor, Johannes Galilee, sought to transform the church's textual culture. Partly driven by his need to depict the church to the bureaucratic apartheid state as a literate-documentary institution, and partly prompted by his need to assert a more centralized authority over the Nazaretha congregation, Johannes created a church bureaucracy. He appointed a secretary, created a church office, and sought to bring believers' decentralized textual production into the orbit of his own authority through producing formally printed, mass-produced texts. Johannes's reign marked a shift from Nazaretha literacy as a collaborative undertaking to a highly centralized act; from a magical technology to bureaucratic expertise; and from texts couched in a spoken idiom to an emphasis on the silent, written page. But important continuities existed. For one, converts' older collaborative reading and writing practices carried over into the period of Johannes's reign. Further, although employing very different textual technologies, both Isaiah and Johannes realized the power of texts to knit their religious congregations into governable constituencies and to withstand the incursion of the frequently hostile state.

This strongly historicized reading of Nazaretha textual activity contributes to a wide literature on reading and writing practices within the Nazaretha church. ${ }^{4}$ Much scholarly attention has been paid to the complex co-existence of written text and performance in the church, and numerous descriptions offered of how, in the largely illiterate congregations of the twentieth century, 'literacy as a mode of social being (was) gesturally present... coupled with the constant reiteration of the performative as a parallel mode of meaning. ${ }^{5}$ But while there is a large and rich body of scholarship on texts and performance within the Nazaretha church, for the most part this scholarship does not analyze the changes in the church's complex literary culture throughout the twentieth century and in particular the shift from the handwritten, spoken texts of Isaiah's day to the more formal production of centrally printed texts in Johannes's period. ${ }^{6}$ For the most part, textual production in the reign of Isaiah over the church is attended to, ${ }^{7}$ and in particular the commitment of Isaiah's hymns to text by his scribes has received a great deal of attention from scholars. ${ }^{8}$ The present article contributes by investigating both the textual production of Isaiah's day, and also discussing the radical changes it underwent after his death in 1935. But alongside these shifts, the present discussion also tracks the important continuities with Isaiah's textual culture discernible in converts' reading and writing practices during Johannes's reign. 
Further, this article situates itself among broader discussions regarding the relationship between literate technologies and varying forms of public life. ${ }^{9}$ The very types of texts Nazaretha converts read and wrote, and the dispositions with which these textual objects were received and consumed have had radical consequences in shaping the nature of reading and writing Nazaretha publics. ${ }^{10}$ The collaborative, handwritten production of scribes constituted very different communities from those assembled by the centralized, mechanical technology of the printing press. In both cases these textual objects underlay the ability of the Shembe leaders to summon up their followers' loyalty and obedience; print culture is closely linked to questions of power and governance. In the South African context in particular, scholars have attended to how the apartheid state's highly bureaucratic culture played a pivotal role in assembling homogenous communities of governable Africans, counted and categorized as 'Bantu' rather than as citizens with a claim to political franchise. ${ }^{11}$ Less work has been done on how apartheid-era African agents themselves mobilized the state's bureaucratic discourse, producing their own array of 'official' documentation in order to further their own communal projectsoften subverting the homogenizing agenda of the state. ${ }^{12}$ Apartheid-era African agents read and created texts in ways that reinvented, shifted, and distorted the official bureaucratic repertoire. ${ }^{13}$ Johannes Shembe's creation of an ecclesial bureaucracy offers a rich example of one such imaginative appropriation of a seemingly hegemonic official documentary culture.

\section{Isaiah Shembe's Miraculous Literacy}

In the early twentieth century Natal and Zululand literate nationalists and public figures were deeply interested in the resources of texts to knit together a new type of polity: the modern, progressive collective of educated Zulu. The literacy they used was an elite, highly privatized practice, largely shaped through the use of the formal printing press. Literacy was cast as a rational technology; an expertise that equipped the amakholwa elite for membership within rational, secular polity of moderns. Throughout the 1920s and 1930s, mission-school-educated and politically active men such as Isaiah's neighbour in Inanda, educator and newspaper editor John Dube, and lawyers George Champion and Pixley Seme were the luminaries of Zulu Christian community, and known as the amakholwa, the believers. Writing and reading was central to their project. Dube's newspaper, Ilanga laseNatal, became a central forum within which varying notions of Zulu identity and its cultural legacy were debated in the first decades of the twentieth century. Zulu writers such 
as these were able to draw on their connections to ensure access to printing presses..$^{14}$ Although the kholwa were by no means uniformly literate and were not all positioned within this writing and publishing elite, ${ }^{15}$ nonetheless an important component of kholwa early twentieth-century identity was the production and reading consumption of centrally printed pamphlets, books, and newspapers.

In contrast to this elite and individualized conception of reading and writing, Isaiah's acquisition of literacy was as a collaborative, relational undertaking. While as children many of his amakholwa peers attended prestigious mission schools, the young Isaiah and his brothers shepherded cattle and goats for the Afrikaans farmer on whose property his father was a labor tenant. ${ }^{16}$ At some point during the 1890 s, when Isaiah was a young man in his twenties, he moved to the nearby town of Harrismith, most likely in the African area in the south of the town known as Skomplaas. ${ }^{17}$ Here he linked himself to a local community of African Methodists ${ }^{18}$ and with them learned to read and also write a little. ${ }^{19}$ For adult, non-elite learners such as Isaiah, a common means of acquiring literacy was through communal reading practices. Men, particularly migrant labourers in towns as Isaiah was during these years, frequently acquired basic literacy through joining reading groups that met at night. Isaiah's son, Johannes Galilee, recalled how his father was soon 'able to read the Bible by himself'20 through this informal system, common in urban migrant work, "whereby one man used to teach another the art of reading and writing. ${ }^{21}$ These collectives of adult learners were led by an individual who usually had 'several years of night school education behind him'. The mode of teaching was strongly oral. The leader would read aloud from texts, thereby rendering them 'into the spoken word for his audience'. ${ }^{22}$

In his informal, collaborative education Isaiah frequently heard the written text of the Bible as a public, spoken utterance. One of the key texts that contemporary adult learners would have read aloud to them and consequently learn to read themselves was the Zulu-language Bible. Most probably, this would have been the translation undertaken by the American Board missionaries in 1883 (revised in 1893), since this seems to have been the Bible Isaiah read and preached from in later life. ${ }^{23}$ Isaiah had heard the Bible read aloud from an early date, even before his Harrismith period. In an interview with Native Affairs clerk Carl Faye in 1930, Isaiah recalled how he would hear the Afrikaans farmer on whose land Isaiah's father lived read the Bible aloud daily. They would 'pray and read the Bible morning and evening... they prayed on waking and on sleeping', and on Sundays they would go into Harrismith town for a service. ${ }^{24}$ In later years migrant labour readers such as Isaiah learned to identify letters and words on the page by drawing on their 
well-established aural repertoire of biblical texts gained over the years from sermons and public readings of the Bible, such as those Isaiah experienced in the home of the Afrikaans farmer. Adult readers would patiently identify 'each letter and syllable until each word, phrase or sentence rings familiar'. ${ }^{25}$ Isaiah's resultant Bible literacy was marked by highly permeable distinctions between reading, speaking, and hearing.

Shaped by the importance of speech, Isaiah's accounts of his own life awarded a central place to the idiom of the spoken voice rather than the written page. In later life Isaiah described how as a young boy praying alone he was often visited by an unknown voice of divine provenance. A well-established church tradition is a story about how Isaiah stole peaches from one of Grabe's fruit trees. On the verge of being discovered, Isaiah hid in the tree and heard a voice in his ear that instructed him, 'Do not look at the white man. Look up to me to whom you pray to!'26 Isaiah's voice was an invisible spiritual resource that defended him against a hostile outside environment. In later years Isaiah would describe how he continued to be guided by the voice, including his decision to leave his wives and undertake a celibate ministry. ${ }^{27}$ A young master's degree student, Esther Roberts, described how when visiting Ekuphakameni Isaiah would frequently choose to sleep in a different building rather than his usual one; these decisions were also prompted by the voice. ${ }^{28}$ And in Isaiah's hymnal compositions the metaphor of the spoken/ heard voice predominated, rather than that of writing. In an oft-quoted 1950s interview by Lutheran missionary Bengt Sundkler, Johannes Galilee characterized his father's style of hymnal composition as aural rather than literary:

Isaiah would hear a woman's voice, often a girl's voice, singing new and unexpected words. He could not see her, but as he woke up from a dream or walked along the path in Zululand, meditating, he heard that small voice, that clear voice, which gave him a new hymn. He had to write down the new words, while humming and singing the tune that was born with the words. ${ }^{29}$

Isaiah explicitly contrasted this collaborative, spoken mode of literacy against the individualized literate accomplishments of modern amakholwa. A recurring idiom throughout Isaiah's sermons and teachings was his distrust of those for whom literacy was a private, individualistic expertise- the 'clever ones' who were mission-school educated. ${ }^{30}$ Within his own settlement of Ekuphakameni he expressed a preference that young converts should receive industrial vocational training rather than book learning. ${ }^{31}$ Rather than a rational, individualistic expertise, Isaiah cast his reading and writing skills as a 
miraculous technology, a gift not only from those who surrounded him but from God as well. In doing so, Isaiah deliberately set himself apart from the mission-educated amakholwa elite. When interviewed by the travelling Native Economic Commission of 1932, Isaiah told the commissioners, 'I have not gone to school and I have not been taught by white people... I have not been taught to read and write'. He went on to tell the commissioners, 'I am able to read the Bible a little bit, and that came to me by revelation and not by learning. It came to me by miracle'. ${ }^{32}$ In a similar fashion, Isaiah told Nellie Wells, a sympathetic European visitor to Ekuphakameni in the 1930s, that during his period of migrant work in Harrismith he began to 'use other native boys' books, and commit signs and symbols to memory'. But alongside these pragmatic efforts, he would also 'pray every night that he might read one day'. ${ }^{33}$ Rather than the fruit of a progressive education, Isaiah interpreted his resultant skill in reading and writing as a miraculous gift bestowed by God.

Further marking his distance from the rational milieu of amakholwa literacy, Isaiah also cast the very material object of a sacred text as a semimagical object, considered to be the physical medium of the very Word of God. ${ }^{34}$ In part, this may have indicated the influence on Isaiah and other Nazaretha converts of the Protestant missionary culture's notion of texts as vehicles of spiritual salvation. ${ }^{35}$ Isaiah himself spoke frequently of his regard for sacred texts as revered, almost magical, objects. He described to Nellie Wells how the Bible of the Afrikaans farming family used to be placed in the 'sitting room... covered with an antimacassar and a vase of paper flowers'. He told Wells that he was fascinated with the book that 'the natives in the kitchen told him was the Word of God'. ${ }^{36}$

\section{Scribes and Collaborative Writing}

In addition to these collaborative, strongly aural reading practices, Isaiah was also keenly interested in producing texts for the use of the growing community of Nazaretha. But just as Isaiah read texts in a collaborative and public fashion, he also wrote his own texts through similarly social practices. To this end, he used literate members of the church as his scribes, known as ababhali in isiZulu (literally, the 'writers'). Many of his scribes were drawn from the small minority of amaNazaretha who were educated at amakholwa mission schools. They were almost all young people, and many were women. One of Isaiah's earliest scribes was a young girl, Sangiwe Magwaza, who had been a student at Inanda Seminary, attached to the American Zulu Mission near 
Ekuphakameni. ${ }^{37}$ Another of Isaiah's early scribes was the young Lazarus Maphumulo from the Edendale temple of iDeni. Lazarus had attended Siyamu School, a well-known amakholwa educational establishment in the progressive Christian settlement of Edendale. ${ }^{38}$ Two of Isaiah's own sons, Johannes Galilee and Amos, were sent to amakholwa John Dube's Ohlange Institute, which neighbored Ekuphakameni, and then to Adams College on the South Coast, the premier boys' boarding school for progressive Zulu of the early twentieth century. On occasion, both boys acted as scribes for their father. ${ }^{39}$ Others had not attended these prestigious schools, and had only some years of basic education. Perhaps Isaiah's most important scribe was a young boy, Petros Dhlomo, who had worked as a laborer in six-month periods for the white farmer whose land his family lived on in the Msinga district. Whatever schooling he did receive would have been minimal and disrupted. ${ }^{40}$ However, Petros had a natural aptitude for the work of recording speech that more than made up for his fragmentary education. Even as a boy, he remembered that 'I had already the ability to listen when somebody said something, to remember it and not forget it'. ${ }^{41}$

While scribes were important for their pragmatic value, enabling Isaiah to produce a great number of texts, these scribes also fashioned writing as a relational rather than an atomistic practice. Writing through scribes invariably involved at least two people. Sometimes Isaiah would travel with his own scribe. One young man from the Edendale temple, Lazarus Maphumulo, seems to have regularly travelled with Isaiah on his missionary journeys, as did Petros Dhlomo from the Msinga district. ${ }^{42}$ At other times Isaiah would simply make use of whoever happened to have writing skills in the congregation he was visiting at the time. ${ }^{43}$

This highly social form of writing generated a semispoken dialogue between narrator and amanuensis. ${ }^{44}$ Of necessity speaker and scribe would sit near each other, perhaps even facing the other, bouncing a text back and forth to each other in oral, written, and finally reread form. MaDlomo offers a sense of the permeable boundaries between speech, writing, and song at these scribing dialogues, describing how the young boy Nwayeni scribed hymn 200 for Isaiah: 'Babamkhulu said to Nyaweni, "Write!" ... he told Nyaweni what to write... the time came and then Babamkhulu said "Bring it to me, my child" ... and then Babamkhulu sang from that paper which had been written'. Frequently these scribing events between Isaiah and his scribe would be a more broadly watched public 'performance'. At the scribing event where hymn 200 was written down, MaDhlomo herself was present, as was 'Ngqulunga and Ntshaba and Mtshali of Nokhesheni'. ${ }^{45}$ Many of Isaiah's pronouncements recorded by scribes took place at large gatherings of the congregation at Ekuphakameni. ${ }^{46}$ 
But the dialogical performance between speaker and scribe was not an equal one. Scribing events carried out between Isaiah and his network of young scribes affirmed the prophet's mastery over modernity, literacy, and educated youth to the watching audience. Through commanding children to write for them, contemporary African elders such as Isaiah neutralized the threat of a potentially threatening literate economy while still using the resources it represented for their own ends. ${ }^{47}$ Drawing on the skills of a younger generation to create church texts also underscored Isaiah's authority over an educated younger generation whom he elsewhere criticized as migratory, atomized 'clever ones'. Isaiah's use of youthful scribes enabled him to harness the material and imaginative resources literacy represented while simultaneously quelling literacy's socially disruptive qualities.

Further, through the handwritten texts these young scribes produced, traditionalists such as Isaiah were able to access and own for themselves a hitherto elite realm of textual production. Before 1940, scribes created handwritten copies of a central church book containing Isaiah's hymns and prayers for a wide range of ordinary church members. ${ }^{48}$ While most church members of Isaiah's day could not afford their own copies of the Zulu-language Bible,$^{49}$ a handcopied exercise book of Isaiah's prayers and hymns was a more attainable document. Petros Dhlomo's sister remembered his work as a young copyist for the amaNazaretha in the Msinga area: 'Petros bought exercise books and he wrote hymns and prayers, and the morning prayer, the evening prayer and the Sabbath prayer. In fact, he made iziblabelelo... He was writing by hand. At that time there was no machine. ${ }^{50}$

In a sermon Isaiah preached in 1933, recorded by Petros Dhlomo, he described how his young scribes 'liberated' the elite, 'locked-away' Bible of the amakholwa. ${ }^{51}$ The handwritten copies of scribes signalled egalitarian access to texts in stark contrast to the elite, expensive products of the formal printing press. Dhlomo's record of Isaiah's sermon describes a Bible that was kept 'in the house of the Pope... (and) kept under lock by him and only read by himself'. The sermon went on to describe how two children, working as servants in the house of the Pope, found the Bible unlocked one day. They read it and realised that 'their nation which had been demolished so badly by war could never be restored unless they would get a book like this one'. The children decided to buy a copybook and copied the whole Bible into it by hand. The children then 'went from home to home and preached about this book'. Although the children were eventually caught and put to death, their handwritten copies of the Bible served to liberate their whole community.

The mechanically printed texts of the amakholwa elite were identical and hence fundamentally interchangeable, giving rise-so Isaiah claimed - to an aggregate of anonymous and undifferentiated youthful 'moderns', free of duty 
and obligation. By contrast, the dense differentiations that characterized Nazaretha believers-a community of generational hierarchies and prophetic authority-were generated by converts' production and consumption of equally idiosyncratic texts. Each handwritten Nazaretha copybook was considered a unique and non-interchangeable text. ${ }^{52}$ Scribes crafted their copybooks with great care. They wrote with a beautiful, elaborate hand, and would decorate each text with embellishments such as ruled lines and squiggles. ${ }^{53}$ Some even included photographs of their scribing author, carefully glued to the pages. ${ }^{54}$ Readers were intimately linked to these highly personalized texts. A handwritten copybook - the very Word of God-was a treasured possession. An elderly believer recalls that in her early childhood her parents kept their copybook of Isaiah's hymns and prayers in a place of pride in the front room. ${ }^{55}$ Among the only items Isaiah had requested to be buried with him at his funeral at Ekuphakameni in 1935 was one of the hardcover books created during his lifetime by his scribes. ${ }^{56}$

\section{Disciplinary Texts}

By the early 1920s, with the extensive assistance of these scribes, Isaiah began to produce a new Nazaretha corpus of written sacred texts. By the time of his death in 1935, there were 'six large books in which (Isaiah's) clerk had written at his dictation parables, addresses and paraphrases of the Bible'. ${ }^{57}$ Isaiah intended the early handwritten collection to be used liturgically—at his dictation, Isaiah's clerk had included material 'suitable for services'. ${ }^{58}$ The first of these books was titled 'The Book for Conducting Religious Services and Other Ceremonies of the Nazarites as Inaugurated, Arranged and Authorised by Isaiah Shembe, Servant of God, Prophet and the Servant of Sorrows of Ekuphakameni, Phoenix, Natal, South Africa. ${ }^{59}$ Isaiah read aloud from the books during services; perhaps the act of reading from a book lent the church an air of establishment gravitas. Roberts mentions that at the funerals of believers, Isaiah would read aloud his burial service from one of his scribed notebooks. Reporting his testimony to church archivist Dhlomo, a believer remembers an occasion in 1928 when Isaiah read aloud one of his parables during the morning service at Ekuphakameni, reading from a 'book with a rough white cover ${ }^{60}{ }^{60}$ Hymns and prayers, which were also read aloud during services, were committed to writing from the 1920 s onward. ${ }^{61}$ These doctrinal texts circulated widely amongst believers; many believers had their own handwritten copybook created for them by scribes. 
In addition to these texts, Isaiah and his scribes also produced documents that had a more explicitly community-building and disciplinary function. Despite the collaborative, participatory nature of Isaiah's literate practices, he was still compelled to exert a disciplinary, cohesive influence on his geographically far-flung body of converts. ${ }^{62}$ Isaiah deputized trusted ministers to these far-away congregations, visiting in person only every few months, or perhaps every year. ${ }^{63}$ But appointing deputies was risky; Isaiah was plagued by the rival ambitions of his ministers. Amos Mzobe was among the first ministers Isaiah had ordained in 1914 atop Mount Nhlangakazi, and he was placed to preside over a Mpondoland congregation. By 1916 Mzobe had broken away and started a rival church. ${ }^{64}$ Perhaps the most threatening ministerial defection was that of Minister Petros Mnqayi in the mid-1920s, whom Isaiah may even have had in mind as his potential successor after his death. ${ }^{65}$ In the early 1920s Isaiah sent Mnqayi to evangelise and supervise a congregation in the remote Msinga district. ${ }^{66}$ Stationed hundreds of miles from Ekuphakameni for several years, Mnqayi grew reluctant to turn his converts over to Isaiah and started a breakaway church. ${ }^{67}$

In performing their disciplinary function these texts nonetheless drew on Isaiah's typically collaborative, relational mode of literacy. They rebuked through idioms of spoken, face-to-face dialogue, addressing believers as particular individuals rather than an anonymous reading public. Isaiah's practice of using scribes to write letters to far-off congregations and individuals drew on the prestige of print, combined with an intimate, relational mode of literacy, to gather his followers into a unified, obedient body. Isaiah's letters capitalized on the law-making capacity of the written word and the direct admonitory force of the spoken voice. A letter narrated aloud by Isaiah to an attendant scribe lent itself admirably to the conveyance of a direct, admonitory word. A letter Isaiah 'wrote 'in 1934 with the assistance of a young boy to Minister Simon Mngoma proclaimed that the text conveyed his spoken voice-what 'I speak to you about today'. ${ }^{68}$ In a letter of the same year, perhaps scribed by the same boy to his errant former right-hand man, Johannes Mlangeni, Isaiah referred to the letter as the 'word that I speak to you now' ${ }^{69}$ And in a scribed letter to the rebellious Petros Mnqayi, Isaiah instructed him to heed the spoken word of his letter: 'Listen to what I say to you today'. ${ }^{70}$ The highly oral nature of letters is conveyed in a record of a missive Isaiah wrote to one Bangizwe Mhlongo. Mhlongo's wife had travelled to Ekuphakameni, bearing news of a misfortune that had befallen her husband. Isaiah dictated a letter to her with the introduction: 'Today, this is what I have to tell you my brother'. He finished by writing to Mhlongo that he looked 
forward to 'hearing all your words' when Mhlongo's wife returned with his letter of response. ${ }^{71}$

Isaiah also directed his words to errant church members. A number of letters Isaiah wrote to rebellious ministers have been preserved by the church. A letter dictated to a scribe in 1934 to the ambitious Petros Mnqayi of the Msinga district exhorted the recipient to 'examine the law' and return to Ekuphakameni with his schismatic fold. Isaiah's falling out with his most senior deputy, Johannes Mlangeni, with whom he had worked in the Orange Free State and whom he had called down to Natal to help him found the church in 1910, and his attempt to recall Mlangeni into the fold were both carried out through the medium of letters, Isaiah also wrote letters through scribes to straying individuals or congregations, similarly rebuking them with the direct address of his word. His letter to the Thembalimbe congregation scolded the young men and women of the congregation-the 'people of Thembalimbe' - for courting each other within the very temple site, and commanded them to repent. He wrote the following: 'I am giving you these words. ${ }^{72}$ Act and be saved'..$^{73}$ Isaiah's admonitory letter to Chief Mthiyane of Mandlazini instructed the chief to not 'play loose and fast with my words'. The hostile chief was reminded not of a universal commandment, but of his expected loyalty to Isaiah's words: 'I am warning you quite specifically, don't ignore the things I've cautioned you about today. These are my very words.$^{74}$

Further, in contrast to the anonymous, antisocial character of amakholwa texts, as he characterized them, Isaiah's letters almost always identified their recipients by name, underscoring the intimate, nature of his disciplining word. A letter was an intimate word between two named parties. Isaiah would instruct his scribes to address letters to particular individuals. Frequently the addressee was an entire community; in 1934 he wrote a missive to the Judea congregation in Zululand, addressing it through his scribe as a 'Letter to the Servants at Judea, in the famous home of God in Zululand, June $6,1934 .{ }^{75}$ A letter to a congregation of Thembalimbe temple began, 'Here are the words that I give to you, people of Thembalimbe'. ${ }^{76}$ Sometimes the addressees of Isaiah's letter were more general, although still identified. Recipients were simply named as 'those who love the Lord'. ${ }^{77}$ Isaiah also claimed the scribed letter as his own. Frequently, he would sign himself off as 'I Shembe', or 'Revd. I Shembe', or sometimes, 'Isaiah, the Servant of Sorrows' ${ }^{78}$ A letter he wrote to Johannes Mlangeni greeted him as 'my child, Mlangeni', and then immediately identified himself as the sender: 'It is I who write these words to you'. ${ }^{79}$

An important example of the intimate, 'naming' power of Isaiah's scribed texts was the 'Book of Life'. During his evangelistic travels, Isaiah drew on 
his attendant scribe or perhaps used a scribe in the local temple to write the names of new believers into a large, hardbound book, as well as to record the names of those converts who had paid their membership dues. ${ }^{80}$ On one level a pragmatic accounts record, believers also viewed the volume as a record of a community 'inscribed' in heaven, an intimate and deeply personalized community in which every believer is identified by name. ${ }^{81}$ Dhlomo remembers that Isaiah said that the book 'attests that your name is written before the saints in heaven. Even if you committed a sin, which had not yet been settled on earth, it will be settled by the archangel Michael, who defends the children of men'. ${ }^{82}$ In the 1930s Isaiah reprimanded ministers of an outlying temple in the Msinga region of Natal for failing to enter new members' names into the book, for 'how will they enter Ekuphakameni (here understood in its heavenly sense) after their death?'83 Nazaretha sermonic tradition has a rich vein of sermons and parables dealing with the theme of arriving at the heavenly gates. ${ }^{84}$ One meets Isaiah at the gates, holding a heavenly book. If fortunate, the deceased will find their name inscribed within it. If one's name is not 'written' in heaven, there is no possibility of entry. Clearly, Isaiah well appreciated literacy's power to regulate entry, circumscribe membership, and conjure up imagined communities. But this documentary regime was a deeply intimate one whereby each 'registered' believer was known by name.

Rather than being studied within the private interiority of the mind, Isaiah instructed recipients of his letters to 'hear' them. In a missive to Minister Petros Mnqayi in 1932, Isaiah commanded Mnqayi to 'listen' to the letter: 'listen to what I say to you today'. ${ }^{85}$ Hearing was an embodied spiritual discipline. As Isaiah told believers in a 1927 address at Groutville, believers 'who drink from the spring of life are those who listen with great care to the words of God' ${ }^{86}$ Isaiah depicted obedient listening as an embodied, wholly consuming spiritual practice: 'a man who has been chosen by God to be a custodian of the Word of God is filled with his Spirit and becomes holy to his bones ${ }^{87}$ Isaiah also employed agricultural metaphors to convey the transformative effect of his words on listeners and readers. In one text Isaiah described the words that he dictated to his scribe as having the effect of 'hoeing the people's hearts so that they may enter into the new God (Thixo) who is amongst us today' ${ }^{88}$ Isaiah's notion of the physical, public nature of the reception of his letters-bearers of his powerful words-is particularly evident in the scribed record of an address he delivered to the community at Rosboom in 1933. He commanded his 'Brown Nation' to 'study and understand carefully' what he wrote to them. But studying and understanding was not typed as silent, internal reading with the eye, but as physical apprehension of his words: "This verse that I say to you, you must listen to it most 
attentively and chew it most thoroughly with your ears, and you must chew it as the cow chews the cud, but in your spirits". ${ }^{89}$

Not only did the recipients of Isaiah's letters devoutly 'chew' over these epistles, but they also circulated them for the general spiritual edification of the congregation. Private letters between Isaiah and another individual often became part of a far more widely read body of Nazaretha sacred writings. For example, letters penned by Isaiah appeared in the handwritten copybooks of the church's sacred writings circulating among believers in the 1930s. Isaiah's letters to Minister Petros Mnqayi seem to have achieved semicanonical status since they appear as a staple item in at least two handwritten copybooks of the period. ${ }^{90}$ Isaiah's admonitory letters to Mnqayi were read as more general devotional texts by believers, who gleaned instruction about the virtues of obedience and humility from their reading of the epistles. The boundary between private letters and more generally addressed doctrinal texts was blurred. The dialogical genre and spoken idiom of the letter served as an important template for the intrinsically disciplinary form of many other church texts.

Finally, as well as using literacy to knit his congregation together into intimate, face-to-face communities, Isaiah also recognized texts' miraculous ability to 'make things stick'. As an early twentieth-century church leader in a precarious world, Isaiah's desire was to establish Nazaretha longevity in the face of persistent opposition from the state. ${ }^{91}$ Isaiah invoked his innovative idiom of spoken literacy to establish enduring Nazaretha presence. ${ }^{92}$ In 1931 the Native Affairs Department ordered Isaiah to abandon several temples that he had established on land granted to him by a number of Zululand chiefs. ${ }^{93}$ Church tradition has preserved a letter that Isaiah wrote to his law firm in August 1931 requesting permission to 'write my presence in stone in these places that are to be dismantled'. ${ }^{94}$ Inscribing the temples' names in stone at the demolished site would ensure that in future years if a 'ruler' came to 'reinstate all these places', he 'would... know all their names'. The written trace of the destroyed temples meant that in future years the church could succeed in reasserting its presence. ${ }^{95}$ As well as stones, the church's sacred dance was also cast as a type of miraculous writing. Dancing is thought to be an act of such power that it leaves an indelible trace of Nazaretha presence in the area in which it is performed. A traditional story still told in the church today relates Isaiah's arrival in the Maphumulo district, and the opposition he faced from the Bomvu chief. The chief ordered Isaiah to leave the area; before he did, as an act of defiance, Isaiah ordered his small Nazaretha following to perform a sacred dance before they left the area 'so that we will write a letter for the chief'. ${ }^{96}$ Nazaretha believers interpreted highly embodied, performative acts of writing as creating enduring spiritual records in the face of opposition. 


\section{Johannes Galilee Shembe: 'The Coming Lord is Very Learned'}

After Isaiah's death in 1935, a major shift occurred away from the collaborative, embodied reading and writing practices that characterized the church of his day. In 1935 his son and successor, the university-educated schoolteacher Johannes Galilee, inaugurated an era of mechanically printed, mass-produced Nazaretha texts. While Isaiah's handwritten texts had invoked the miraculous idiom of the spoken word-frequently used to discipline his followersJohannes's texts instead capitalized on the authority of the written page and the printing press. In part, this shift was prompted by the increasing bureaucratization of the apartheid state. Johannes and the AmaNazaretha congregation were subjected to the documentary surveillance of a state obsessed with using bureaucracy to count, categorize, and order its subjects. Johannes himself made creative use of these technologies, not only to favourably present his church as a bureaucratic-literate institution to the apartheid state, but also to better govern his frequently recalcitrant congregations. A formally produced hymnal, catechism, and an array of church documentation such as certificates, passes, and heavenly 'tickets' all affirmed his centralized authority. As did the apartheid state, Johannes recognized mass-produced print's ability to summon up homogenous and uniform constituencies. Nonetheless, important continuities with the textual culture of Isaiah's day were still discernible. Ordinary believers both read texts and produced new ones in inventive ways that occasionally subverted Johannes's homogenizing textual agenda. Converts continued to affirm the spoken register of written texts, as well as the magical-thaumaturgical properties of sacred documents. Believers' reading practices refused to reduce church texts to Johannes's authorial intentions alone, continuing instead the decentralized, collaborative textual practices that had characterized the church of Isaiah's day.

Johannes was well positioned to transition the church from the handwritten scribing practices of Isaiah's day to its new era of centralized print culture. Recognizing the social and moral capital inherent of the written word, Isaiah had ensured that his sons would be at home within the elite world of kholwa literates. Isaiah sent both Johannes Galilee and his younger brother, Amos, to John Dube's neighboring Ohlange School for their secondary education. Johannes's final three years of secondary school (1923-1926) were at Adams College (or the Amanzimtoti Institute as it was known until 1935) on the coast south of Durban. ${ }^{97}$ The American Board Mission had founded Adams in 1853 for the purposes of training young African men for teaching careers and the ministry, and was one of the preeminent African educational institutions of the day. ${ }^{98}$ Both Johannes and Amos then went on to study at the country's only African university, Fort Hare in the Eastern Cape. Johannes 
obtained a BA in 1931, with a major in ethics and psychology. ${ }^{99}$ After graduating from Fort Hare, Johannes returned to Adams, this time as a teacher. His several years of teaching at Adam's placed him among the literate African elite of the day: leading kholwa public figures such as John Dube, George Champion, Chief Albert Luthuli, and Z. K. Matthews were all teachers there during the first decades of the twentieth century.

In keeping with his elite education, Johannes's conception of literacy was a modern, rational capacity accessed in private through the 'mobility of the eye' rather than the spoken idiom of the direct voice. ${ }^{100}$ Johannes himself juxtaposed his modern, written literacy against his father's miraculous mode of spoken literacy. In an interview with Sundkler in 1969, Johannes contrasted his father's manner of composing hymns through hearing heavenly voices, which he would then dictate to his scribes, with his own process by which he would 'see the new hymn written on the blackboard of the mind, lowered down before his eyes. Then he had to write down the verses straight away'. ${ }^{101}$

In many respects, Johannes identified his literate abilities with the self-improving, modernizing aspirations of the amakholwa elite. For this educated African elite, education was key to the attainment of political franchise. In the early 1930s Johannes and Selby Ngcobo-a fellow teacher at Adam's and future professor of economics at the University of Botswana ${ }^{102}$ - both began campaigning for the college to introduce non-white tertiary education through the University of Natal. ${ }^{103}$ In 1935 , the year he took over leadership of the church, Johannes was appointed to the advisory board of the college in company with prominent African intellectuals and political figures such as Albert Luthuli and John Dube. ${ }^{104}$ One church member who worked as Johannes's driver during the 1950 s remembers how the prophet counseled believers to educate themselves in preparation for political autonomy 'because the rulership is coming to the Brown people, but the people do not understand it, and because their children have not been educated, they will remain slaves of other people... therefore, educate your children'. ${ }^{105}$

\section{Government Recognition}

The textual culture of the Nazaretha church of Johannes's day was expressed through a strongly bureaucratic idiom. This was linked to important shifts in the wider textual culture of the day. While the South African state had always invested in the power of print to govern its subjects, the apartheid state, which formally came into power with the victory of the Nationalist Party in 1948, drew more heavily than ever on documentary bureaucracy to order, 
label, count, and categorize its African subjects. From at least the late ' $40 \mathrm{~s}$ onward, the state's policy was to create homogenous 'ethnic' groupings, including a large population bloc categorized as 'Bantu'. The deeply interchangeable units that made up the category 'Bantu' were considered more governable than a heterogeneous population. For one, by this uniform category of Bantu the government could disqualify all Africans-educated or not-from political franchise within South Africa, a European state. The state's bureaucratic culture played an important role in the creation of governable aggregates of anonymous Bantu, assembling Africans as numbers rather than as political citizens. ${ }^{106}$ The state's apparatus of identification and travel documents and its penchant for frequent censuses classified Africans as anonymous numbers rather than as individuals, positioning them as faceless components of as a series known as Bantu rather than as potentially troublesome members of religion, class-based, and political groupings.

The proliferation of African Independent churches such as the AmaNazaretha was an affront to the state's logic of identical, rigorously counted Bantu. While in theory the apartheid state approved of the notion of a 'separate Bantu religion, in practice it was deeply skeptical about the degree of sectarianism among these churches. The 1956 Tomlinson Report declared that these 'splinter movements'-1, 286 of which were known to the Departmentwere 'harmful ... to the general development of the Bantu'. ${ }^{107}$ In 1945 there were 800 independent churches known to the government. By 1960 the number had shot up to 2,200. ${ }^{108}$ The Native Affairs Department (NAD) fretted about the mushrooming of African religious activity, describing the proliferation of these churches through idioms of contagion, mutation and uncontrollable replication. ${ }^{109}$ The government frequently perceived these mushrooming churches as representing a serious political threat. The killing of two European policemen in the Nongoma district in 1941, allegedly by members of the Nazaretha church, was an important factor in the state's anxiety about the undisciplined profusion of congregations around the country. ${ }^{110}$

In order to contain this seemingly chaotic multiplication of churches and the attendant political threat they represented, the government instituted a system of bureaucratic surveillance known as 'recognition'. The state sought to categorize the prolifically 'unstable and irresponsible' phenomena of African-led churches within their panoptic bureaucracy. In order to gain allimportant privileges such as permission for church and school sites in native territory, ministers' registeration as marriage officers, railway travel concessions for ministers, and the ability to buy wine for sacramental purposes, all independent churches had to seek written recognition from the Native Affairs 
Department. ${ }^{111}$ Without recognition, an African-led church such as the AmaNazaretha faced almost insurmountable difficulties. In the early $1940 \mathrm{~s}$ the government initiated a stringent crackdown on a number of important Nazaretha temples in Zululand, built on Reserve land and controlled by chiefs who belonged to the church. ${ }^{112}$ The state pulled down the temples, claiming that, as an unrecognized body, the Nazaretha church was not entitled to occupy church sites on Reserve land and, most importantly, did not own the appropriate documentation. Johannes wrote to the department annually, not only seeking official recognition for but also for permission for virtually every aspect of the church's life, including permission to undertake annual pilgrimages to nearby Mount Nhlangakazi and to erect temple sites.

However, the possibility of government recognition for the AmaNazaretha was almost non-existent; only eleven of the 2, 200 African-led churches ever gained this status throughout the twentieth century. Johannes himself made multiple unsuccessful applications throughout the decades of his rule. ${ }^{113}$ The endless letters and documentation that passed between Native Affairs and applicant churches clearly served a purpose other than actually leading to recognition, they enabled the Department of Native Affairs to keep tabs on these movements, to quite literally count them. Johannes's numerous applications were made up of lengthy legal and mensurational documentation: church registers supplying numbers of members in regional temples; names, addresses, educational certificates, and pass documents of ministers; and maps of the church's properties, bank balances, and moral 'accounts' in the form of testimonies to his ministers' characters. ${ }^{114}$ Many applicants hired a lawyer to help them summon a suitably official array of documentation; Johannes himself made use of lawyer and trade unionist George Champion. ${ }^{115}$ Applicants invariably received a standard, typewritten rejection from the Native Affairs Department with an affixed registration number. While this number did not award the church recognition, it did mean that the institution had now been counted and categorized by the NAD's bureaucracy: for 'each of these 2000 plus churches there was now a special file with a number in the Government office'. ${ }^{116}$

As part of his ultimately unsuccessful efforts to present the church to the state as a bureaucratic, literate institution-and to submit ministers' school certificates to the state- Johannes also encouraged his following to educate themselves. Within the church's popular imagination, this could take the form of his divine intervention; one believer recalled that Johannes provided his sister with miraculous assistance in passing her exams. ${ }^{117}$ Johannes also pushed for educating ministers, as well as attempting to provide existent ministers with formal theological training. He may have asked the Lutheran The- 
ological Seminary in Maphumulo for assistance in this regard. In the 1960s two Nazaretha ministers studied at an evangelical seminary outside Pietermaritzburg for two years, although they were expelled for 'non-conformity' in their third year. ${ }^{118}$ Despite Johannes's efforts to encourage education among the Nazaretha, however, the average level remained low. In 198123 percent of Nazaretha believers were estimated to have no education whatsoever, and of the remaining portion the average educational attainment was Standard 3 and 4, equivalent to the last years of primary school. ${ }^{119}$ In 1946, in one of his annual applications to the Chief Native Commissioner (CNC) for recognition, Johannes apologized for this: 'Our ministers are nearly all old men who were appointed during my father's lifetime... they are not educated people. ${ }^{120}$

A more successful step Johannes took in the direction of styling the church as a modern, literate institution - hopefully worthy of bureaucratic recognition from the state-was his institution of a centrally produced, mechanically printed hymnal in 1940, and in later years a catechism as well. It was perhaps no coincidence that the eleven churches that enjoyed recognition by the 1950s were all originally linked to mission denominations, and all possessed formal hymnals, constitutions, and catechisms. ${ }^{121}$ By emulating the printed documents of the mission churches - some of which did possess government recognition-Johannes sought to style the AmaNazaretha as a homogenous community to the state, consisting of thousands of identical converts all, quite literally, on the same page.

\section{Bureaucracy and Governable Congregations}

Although Johannes's efforts to cast the church as a bureaucratic, literate institution were ultimately unsuccessful, ${ }^{122}$ he nonetheless made strategic use of this same print culture in order to discipline his own Nazaretha congregations. Convincingly counting his converts in the hopes of seeking documentary privileges from the state was not his only challenge. Particularly in the early years of his reign, Johannes also faced significant internal rivalry to his leadership. Johannes's difficulty in establishing his authority as his father's successor stemmed partly from the huge growth of the church. When Isaiah died in 1935, the Nazaretha congregation was estimated at about 30,000; by the time of Johannes's death in 1976 there were 250000 believers. These tens of thousands of believers were dispersed across the country as well as outside South Africa's borders. Following his formal election as leader of the church in July 1935 by a church council appointed by his father, rival claims on 
Nazaretha believers' loyalty arose. In 1940 his younger brother Amos broke away with a rival faction. This was soon defeated. ${ }^{223} \mathrm{~A}$ more serious threat was a woman 'from the north', whom church tradition has preserved as Umphefumulo, the 'Spirit'. ${ }^{124}$ Several years after Isaiah's death, she claimed that his spirit had taken up residence in her body; consequently, she was called Umphefumulo, the spirit of Isaiah. With three younger female assistants, she claimed to receive her revelations by visiting the mausoleum built over Isaiah's grave at Ekuphakameni, and having lengthy conversations with the prophet.

Echoing the literary devices of the apartheid state, Johannes well realized that assembling his followers around mass-produced, formally printed texts led to a greater degree of governability. Along these lines, one of Johannes's important innovations in formalizing textual production was his appointment of a church secretary who was officially responsible for the creation of all printed texts in the church. This role was filled by the same Petros Dhlomo of the Msinga district whose writing skills Isaiah had drawn on in committing his hymns to writing throughout the 1920s and 1930s. In 1949 Johannes requested that Dhlomo leave his job as a migrant worker in Johannesburg and take the full-time job of scribing believers' memories of Isaiah Shembe, and centrally archiving texts already created by local scribes. Johnanes gave Dhlomo a typewriter and installed him in a church office. Dhlomo's niece, Bongiwe Mchunu, recalled that in the mid-1970s she moved to Ebuhleni to assist her uncle in his archival and secretarial work, as well as to cook and clean for him. She remembered that her uncle spent

\begin{abstract}
most of his time in the office... he was doing things like certificates, those who were baptized he made certificates for them, and those who were getting married he made certificates for them. And then the hymn books, they [Dhlomo and his assistants] are the ones who wrote them and bound them. They would type them and they became what they are today. ${ }^{125}$
\end{abstract}

One of the effects of a having a centralized secretary and a formal church office was that believers' independent textual production-previously epitomized in the activities of scribes—was radically undercut. For one, Johannes used his secretary, Dhlomo, to exercise control over the handwritten stories believers' produced about their encounters with Isaiah. During Isaiah's lifetime a prolific flow of texts dealing with his miraculous life emerged, largely penned by independent, literate members or narrated by Isaiah himself to an attendant scribe or scribes. After his father's death in 1935 Johannes continued to encourage believers and scribes of local temple communities to record 
their and their communities' memories of his father, but he simultaneously began to regulate their production: he instructed Nazaretha to bring their stories to Dhlomo, who would type the stories, and lodge them at a central archive in Ekuphakameni. ${ }^{126}$ By the late 1930s Johannes had requested all 'who had been writing about his father to bring their work to the office, and those who knew anything about him to start writing without delay'. ${ }^{127}$ At the end of Lazarus Maphumulo's notebook he wrote a 'self-reminder': 'It is important that you write these things down and give them to the king at Ekuphakameni'. ${ }^{128}$

Mechanisms such as a typewriter, officials such as a secretary, and the institution of an archive all enabled Johannes to craft his followers' individual testimonies into an official ecclesial bureaucracy. Petros Dhlomo transcribed these testimonies that were submitted both in handwritten and oral form by believers into typewritten pages. He divided and numbered the texts by verse numbers, much in the style of an extracanonical gospel. ${ }^{129}$ Dhlomo then filed the texts in a cabinet at the church office. ${ }^{130}$ By the end of Johannes's reign in the mid-1970s, Dhlomo had produced over 550 'narrow-typed folio pages'. ${ }^{131}$ Although hagiographical texts had always been produced in the church, the difference now was that through the typewriter, church office, and file cabinet Johannes and Dhlomo were able to archive these documents and thus exercise exclusive, centralized control over the process.

Alongside these archived documents, Johannes and Dhlomo's centrally produced texts also entered into widespread circulation in the church, exerting an important influence in undercutting the decentralized, collaborative mode of literacy of Isaiah's period. The most important of these was the formally printed hymnal produced in 1940, the same year as the threat from Umphefumulo, Johannes's rival to prophetic authority. Johannes used a local Durban publisher, Shuter and Shooter, to produce a formal single volume of the hymnals and prayer services in place of the informal handwritten circulation of material via scribes that had characterized his father's reign. ${ }^{132}$ Although Johannes later composed many of his own hymns, the first 1940 edition of the hymnal contained only his father's compositions. The hymnal was prefaced by an introduction by Johannes in which he underscored the divine provenance of the hymns, and hence the spiritual standing of his father: 'The majority of these hymns came with messengers of heaven'. ${ }^{133}$ His intention at this point was to underscore his role as the exclusive editor of these miraculous song forms instituted by Isaiah and, by extension, the rightful guardian of Isaiah's entire religious legacy. In a different context, Johannes's desire for sole editorial control can be seen in his rejection of kholwa statesman John Dube's biography of his father. ${ }^{134}$ While visiting Ekuphakameni 
for the annual July meeting, Johannes informed Dhlomo that he did 'not like that the work of God should be done by unbelievers'. ${ }^{135}$ Controlling the production of written words was key to Johannes's control of the whole church.

The very mode of the new hymnal's textual production was important. In addition to the content itself and Johannes's preface, it was the hymnal's existence as a mass-produced, printed text that did much of the work of knitting together a body of obedient followers. Through consuming a uniform and infinitely replicable text, readers assembled themselves into a homogenous, undifferentiated readership. Unlike the personalized, spoken texts of Isaiah's era, the mass-produced hymnal addressed all readers alike, irrespective of their individual differences. The varying identities of both author and reader were rendered invisible through the anonymous uniformity of these mass-produced texts. In a similar vein, mass-produced hymnals now had to be bought, further underscoring the transition from handwritten notebooks as handmade personal creations of a scribe to texts as uniform, infinitely replicable commodities. Further, while the technology of handwritten copying had enabled a degree of individual interpretation and appropriation, the centrally printed and mass-distributed 1940 hymnal eliminated any sense in which the text was the believer's own creation. Formally printed, centrally produced documents disseminated a single, orthodox version of the text, closed to the interpretations of individual scribes and their varying writing styles. Finally, the technology of print asserted an elite monopoly over textual production. Instead of the egalitarian access handwritten texts afforded, only educated and relatively wealthy elites - a group within which, thanks to Johannes's early education, he comfortably sat-could use the mechanized printing press to produce texts.

In addition to the homogenizing, centralized regime of the hymnal, Johannes also attempted to consolidate a uniform Nazaretha identity through his production of a printed catechism. Johannes and Dhlomo's published catechisms from 1963 and 1970 supplied a definitive code of Nazaretha belief and practice, creating for the first time an explicit textual criteria for evaluating membership within the church. In 1963 Johannes published a booklet containing the Nazaretha catechism, or Mngcwabo. The Mngcwabo was a compilation of his father's prayers and teachings (or 'counsels'), and integrated material that would probably have been contained in the circulating handwritten notebooks of Isaiah Shembe's era. A second version of the Mngcwabo appeared in 1970, with added material that Johannes Galilee himself had authored. ${ }^{136}$ Included in this new catechism were Johannes's written pronouncements on the correct conduct of ministers; virtuous comportment for young girls within the church; the importance of 'hygiene'; and the order 
for Nazaretha liturgical life, including marriage, funerals, baptism, and daily prayers. At the end of the Mncgwabo there is a formal 'Catechism of the Nazarites', which consists of a question and answer creedal statement-much in the style of mission-church catechisms. The appearance of the catechisms may have indicated both the church's numerical growth in the 1960s and 1970s, and the increasing range of new and ever-growing churches-including Zionists, Apostolics, and Pentecostals—during this period. ${ }^{137}$ A written catechism established a uniformly held code of Nazaretha comportment and, by extension, assisted in knitting the community together as a cohesive community whose identity was strongly differentiated from rival Christians.

Finally, in addition to the printed hymnal and catechism Johannes and Dhlomo produced a range of pseudobureaucratic texts such as tickets, certificates, and passes. Echoing the disciplinary intent of the documentary state, these texts - which wrote believers names' in heaven rather than in the Native Affairs Department—achieved the comparable work of assembling Nazaretha converts into uniform, homogenous constituencies. The idiom of the Book of Life, as a type of passbook that circumscribed entry frequently appeared in sermons during the years of Johannes's reign. Indeed, the personalized appellations of the Book of Life-a register by name of all members of all local temples-had been particularly well suited to the smaller, more intimate communities of Isaiah's day. But in Johannes's era another genre came to prominence, perhaps more suited to a homogenous aggregate of uniform, anonymous converts. This was the frequently heard sermonic idiom of a spiritual ticket, a type of identical, stamped pass without which entry into heaven was forbidden. ${ }^{138}$ Unlike the Book of Life tickets did not carry believers' names, offering only an anonymous number. Certificates were another main area of Johannes and Dhlomo's textual activity. These membership certificates were typed, photocopied, and cut by Dhlomo, then signed and dated by Johannes, for the possession of every believer. ${ }^{139}$ Increasingly, Nazaretha membership was signaled by converts' possession of mass-produced, official documentation. ${ }^{140}$

\section{Arts of Textual Production ${ }^{141}$}

The uniform, cohesive disposition Johannes sought to foster by these formally printed texts did not exhaust the uses of print objects among the AmaNazaretha. Although Johannes may have intended these mechanically printed texts to address converts as undifferentiated, and hence governable, readers, ${ }^{142}$ the literate practices of Nazaretha converts of Johannes's period 
suggest that these texts were read in a wide variety of ways. For one, indirect evidence suggests that the highly social reading practices of Isaiah's day persisted into Johannes's reign. The hymnals were highly popular among believers. Five thousand copies were produced in several reprints throughout the '40s, '50s, and '60s. ${ }^{143}$ But although we may assume that most families had access to a copy of the hymnal, these figures do not suggest that most individuals owned a personal copy. A hymnal was thus a communal rather than an individual possession. Further, from years of church services and hearing the hymns and liturgies sung and recited, almost all believers would have had an intimate aural knowledge of the texts contained in the hymnal. Combined with the low levels of literacy in the community of Johannes's day, ${ }^{144}$ these facts meant that Nazaretha believers were not, on the whole, privately reading the hymnal in their individual worship. Its uses were collective and necessitated common decipherment, those who knew how to read leading those who did not. ${ }^{145}$

Quite possibly the popularity of hymnals among converts of Johannes's era may be understood in terms of the social and spiritual prestige held by the presence of a formally printed book within a household, rather than as a document that believers silently followed with their eyes during the course of worship. ${ }^{146} \mathrm{MaDhlomo}$, a convert from the Msinga district, describes how her hymnal-the book — was an important ritual element in her devotional practice in the 1950s:

I just entered my house, put on my imNazaretha (white prayer gown) and took a mat and took my book and then I would sing. I would call my son and say, "Come let's go and pray". And he would come and the others would follow him. I would put a mat down for them and I would sit on this side and I would open my book, and then I would talk to God, and I would talk some more to God, until I would finish. ${ }^{147}$

Alongside her prayer mat, prayer gown, singing and praying ('talking to God'), MaDhlomo's book (incwadi) was a key element of her worship. The book is described less as a conveyer of information than as a central object in the unfurling order of worship, an integral part of a practiced, smooth sequence of song and prayer. In this vein, the hymnal was frequently used as a talisman, a semimagical document whose presence afforded protection in dangerous situations. For example, one believer preached on the presence of the hymnal in their bag protecting them from the dangers of township life at night. ${ }^{148}$ It was not only the actual text of the hymnal that was thought to convey miraculous powers, photographs of Isaiah and Johannes Shembe were common features of most hymnals and considered to possess potent spiritual power in their own right. One church member from Msinga—a region noto- 
rious for its high levels of violence-described how when stopped by the apartheid state police he fixed 'the photographs of the Lord ... to my clothes'. The sacred images miraculously delivered him from the danger the policemen posed to him: 'Three whites of the rifle searchers' squad saw these photographs, (they) were smiling and kind to me'. ${ }^{149}$ Finally, the incorporation of these photographs into the hymnal was a work of personal creativity. Rather than buying an already decorated text, believers would select photographs of 'Shembe' and paste them to the cover of their hymnal in an unregulated, personal act of ornamentation.

It was not just believers' reading practices that continued to demonstrate their highly differentiated, creative uses of the text. Alongside Johannes's move toward codified, centralized print forms, Nazaretha textuality continued to be characterized by the free, local production of texts, written but also spoken. Despite Johannes's attempt to have all handwritten notebooks lodged at Ekuphakameni, handwritten notebooks continued to circulate in local communities throughout the 1950s and 1960s. One known example is the Memela notebook, dating from around 1954, which consists of 44 pages with no cover. ${ }^{150}$ In 1967, while visiting the church for its January pilgrimage to Nhlangakazi, Becken noted that during Johannes's sermon on the Sabbath 'several men and women were taking notes in order to be able to report to their people at home what the prophet told them'. ${ }^{151}$

Aural texts were less easy to regulate than written texts. An important innovation of the late 1960s, which continued egalitarian decentralized production of texts although it signaled the end of the era of handwritten notebooks, was the introduction of tape cassette technology. As early as 1968 Nazaretha believers began to use hand-held portable cassette recorders to record sermons delivered both by Johannes and by local ministers in home temples. ${ }^{152}$ Indicating the growing popularity of this practice and Johannes and Dhlomo's ambivalence about the insubordinate potential of believers' unregulated recording, their catechism of the 1970s attempts to regulate the use of this technology. ${ }^{153}$ Gradually replacing the practice of notebooks, believers accumulated personal collections of tape cassettes, an aural archive of years of numerous sermons listened to and recorded. Up to the present day, a common sight in a Nazaretha household is a collection of carefully marked tape cassette recordings of numerous sermons, both from the local temple community as well as aural records of sermons delivered at the church's big annual meetings. These tapes are often replayed within the context of family devotional life.

Evoking the handwritten notebooks of Isaiah's era, believers' records of sermons in tape cassettes were personal, self-made creations that opposed the homogenizing regime of centrally produced, mass-distributed printed text. 
Believers themselves exercised judgment over which sermons to record and at which point to stop recording. Further, creating and listening to tape-cassette sermons was not a passive act of receiving top-down pronouncements. Rather, Nazaretha believers considered, and still consider, the act of listening to cassette recordings of sermons to be a spiritual discipline, an exercise in ethical self-improvement. Listening to stories of Shembe's miraculous deedsthe main substance of Nazaretha sermons - was a means for believers to train themselves in the virtues of faith and obedience to the church's teachings. ${ }^{154}$ Alongside Johannes's attempt to create a centrally authorized canon of church texts, believers from a range of local temples have continued to accumulate their own personal archives, consisting of both written and oral texts, and employing electronic media to do so in later years.

\section{Conclusion}

This six-decade history of textual production in the Nazaretha church has sought to illuminate the history of the very community itself. The church's documentary history provides insight into the efforts of its leaders to use texts to govern, centralize, and discipline their geographically far-flung, often unruly, congregations. But in addition to focusing on the documentary regime instituted by the church's leaders and those in charge of producing texts, this article also begins an exploration of the reading and writing practices that animated ordinary believers. For laity as much as for leaders, texts and a general range of literate practices were a means of knitting themselves together, in opposition to the incursion of the state and in distinction to contemporary rival Christians. Nazaretha readers and writers have also used texts in ways that have subverted the lessons church leadership has attempted to impose upon them. Finally, this article has also sought to position these texts as significant objects in their own right, to explore the effects of meaning that the material form of the text produces. Nazaretha documents' changing forms - handwritten, typewritten, aural-have both engaged with contemporary textual cultures as well as exerted formative influence on the constitution of the Nazaretha community.

\section{References}

Anderson, Benedict. 2006. Imagined Communities: Reflections on the Origin and Spread Nationalism. New York: Verso.

Barber, Karen. 1997. 'Preliminary Notes on Audience in Africa'. Africa: Journal of the International African Institute 67.3, 347-362. 
2006. Africa's Hidden Histories: Everyday Literacy and the Making of the Self. Indianapolis: University of Indiana Press.

. 2007. The Anthropology of Texts, Persons and Publics. Cambridge: Cambridge University Press.

Becken, Hans Jurgen. 1966. 'The Nazareth Baptist Church of Shembe'. In Our approach to the Independent Church Movement in South Africa. Natal: Missiological Institute Mapumulo, 1966.

. 1967. 'On The Holy Mountain: A Visit to the New Year's Festival of the Nazaretha Church on Mount Nhlangakazi January 14, 1967'. Journal of Religion in Africa I, 138-149.

. 1978. 'Ekuphakameni Revisited: Recent Developments Within the Nazaretha Church in South Africa'. Journal of Religion in Africa 9, 161-172.

Breckenridge, K. 2006. 'Reasons for Writing: African Working-Class Letter-Writing in Early Twentieth Century South Africa'. In K. Barber (ed.), Africa's Hidden Histories, $143-155$

Brown, Duncan. 1999. 'Orality and Christianity: The Hymns of Isaiah Shembe and the Church of the Nazarites'. In D. Brown (ed.), Oral Literature and Performance in Southern Africa. Oxford: James Currey.

Burchell, D. E. 1984. 'Adams College, Natal, c. 1920-1956: A Critical Assessment'. The Journal of the University of Durban-Westville New Series 1, 151-159.

Burns, Catherine. 2006. 'The Letters of Louisa Mvemve'. In K. Barber (ed.), Africa's Hidden Histories. Indianapolis: Indiana University Press, 78-112.

Champion, George. 1982. The Views of Mahlati: Writings of AWG Champion a Black South African. Durban: Killie Campbell Press.

Chartier, R. 1994. The Order of Books: Readers, Authors and Libraries in Europe between the Fourteenth and Eighteenth Centuries. Cambridge: Polity Press.

Claasen, Johan. 1995. 'Independents Made Dependents: African Independent Churches and Government Recognition'. Journal of Theology for Southern Africa 91, 15-34.

Clancy, M. T. 1993. From Memory to Written Record: England, 1066-1307. Oxford: Blackwell.

Cobley, Alan Gregor. 1991. 'The African National Church: Self Determination and Political Struggle among Black Christians in South Africa to 1948'. Church History 60, 3.

De Certeau, M. 1984. The Practice of Everyday Life. Berkeley: University of California Press.

Dube, John. 1936. Ushembe. Pietermaritzburg: Shuter and Shooter.

Dubow, Saul. 1986. 'Holding a Just Balance between White and Black: The Native Affairs Department in South Africa, c. 1920-33'. Journal of Southern African Studies 12.2, 217-239.

Evans, Ivan. 1997. Bureaucracy and Race: Native Administration in South Africa. Berkeley: University of California Press.

Fernandez, J. W. 1973. 'The Precincts of the Prophet: A Day with Johannes Galilee Shembe'. Journal of Religion in Africa 5.1, 32-53.

Gunner, Elizabeth. 1986. 'The Word, the Book and the Zulu Church of Nazareth'. In R. Whitaker and E. Sienaert (eds.), Oral Tradition and Literacy. Durban: Natal University Oral Documentation and Research Centre.

- 1988. 'Power House, Prison House: An Oral Genre and Its Use in Isaiah Shembe's Nazareth Baptist Church'. Journal of Southern African Studies 14.2, 204-227. . 2002. 'Dislocation, Memory and Modernity: the Prophet Isaiah Shembe and the Search for Voice and Space', in J. G. Deutsch, H. Schmidt, and P. Probst (eds.), 
African Modernities: Entangled Meanings in Current Debate. Oxford: James Currey, 67-81.

. 2006. 'Keeping a Diary of Visions: Lazarus Phelalasekhaya Maphumulo and the Edendale Congregation of amaNazaretha'. In K. Barber (ed.), Africa's Hidden Histories: Everyday Literacy and Making the Self, 155-179.

- (ed.). 2002. The Man of Heaven and the Beautiful Ones of God: Umuntu wasezulwini nabantu abable bakankulunkulu: Writings from Ibandla lamaNazaretha, a South African Church. Leiden: Brill.

Habermas, Jurgen. 1962. The Structural Transformation of the Public Sphere, trans. Thomas Burger and Frederick Lawrence. Cambridge, MA: MIT Press.

Hermanson, Eric. 2002. 'A Brief Overview of Bible Translation in South Africa'. Acta Theologica Supplementum 2, 6-17.

Herzfeld, M. 1995. The Social Production of Indifference: Exploring the Symbolic Roots of Western Bureaucracy. Chicago, IL: University of Chicago Press.

Hexham, I. (ed.). 1994. The Scriptures of the amaNazaretha of Ekuphakameni: Selected Writings of the Zulu Prophets Isaiah and Londa Shembe. Calgary: University of Calgary Press.

Hexham, I. and G. C. Oosthuizen (eds.). 1996. The Story of Isaiah Shembe: History and Traditions Centered on Ekuphakameni and Mount Nhlangakazi, Volume One. Lewiston: Edwin Mellen Press.

- 1997. The Story of Isaiah Shembe: Early Regional Traditions of the Acts of the Nazarites, Volume Two. Lewiston: Edwin Mellen Press.

. 2001. The Story of Isaiah Shembe: The Continuing Story of the Sun and the Moon, Oral Testimony and the Sacred History of the AmaNazarites Under the Leadership of Bishops Johannes Galilee Shembe and Amos Shembe, Volume Three. Lewiston: Edwin Mellen Press.

Hirschkind, C. 2001. 'The Ethics of Listening: Cassette-Sermon Audition in Contemporary Egypt'. American Ethnologist 28.3, 623-649.

Hofmeyr, Isabel. 2004. The Portable Bunyan: A Transnational History of the Pilgrim's Progress. Princeton, NJ: Princeton University Press.

_. 2006. 'Reading Debating/Debating Reading: The Case of the Lovedale Literary Society, or why Mandela Quotes Shakespeare'. In K. Barber (ed.), Africa's Hidden Histories: Everyday Literacy and Making the Self. Bloomington and Indianapolis: Indian University Press, 258-278.

Houghton, Hobart. 1956. The Tomlinson Report: A Summary of the Findings and Recommendations in the Tomlinson Commission Report. Johannesburg: The South African Institute of Race Relations.

La Hausse, Paul. 2000. Restless Identities: Signatures of Nationalism, Zulu Ethnicity and History in the Lives of Petros Lamula and Lymon Maling. Pietermaritzburg: University of Natal Press.

Landau, Paul. 1995. The Realm of the Word: Language, Gender and Christianity in a Southern African Kingdom. London: James Currey.

Lenta, Ashlee. 2006. 'The Merits of Print for Thembu Praise Poet David Manisi'. Research in African Literatures 37.3, 45-64.

Marks, Shula. 1975. 'The Ambiguities of Dependence: John L. Dube of Natal'. Journal of Southern African Studies 1.2, 162-180.

McKenzie, D. F. 1999. Bibliography and the Sociology of Texts. Cambridge: Cambridge University Press.

Mitchell, Timothy. 1988. Colonizing Egypt. Cambridge: Cambridge University Press. 
Muller, Carol. 1997. 'Written into the Book of Life: Nazarite Women's Performance Inscribed as Spiritual Text in Ibandla lamaNazaretha'. Research in African Literatures 28.1, 3-14.

. 2003. 'Making the Book, Performing the Words of Izihlabelelo zamaNazaretha'. In J. Draper (ed.), Orality, Literacy and Colonialism in Southern Africa. Pietermaritzburg: Cluster Publications, 91-111.

Muller, Carol and B. Mthethwa (eds.). 1996. The Hymns of the Nazaretha. Unpublished manuscript.

Oosthuizen, G. C. 1967. The Theology of a South African Messiah: An Analysis of the Hymnal of the Church of Nazarites. Leiden: Brill.

. 1981. 'Succession Conflict Within the Church of the Nazarites'. Institute for Social and Economic Research, University of Durban-Westville 13, 1-71.

- 2000. 'The African Independent Churches in South Africa: A History of Persecution'. Emory International Law Review 14, 1089-1120.

Opland, Jeff. 1998. Xhosa Poets and Poetry. Claremont: David Philip Publishers.

Papini, Robert. 1997. 'A Sourcebook for the Study of the Church of Nazareth: A Bilingual Publication Project for the Shembe Protoscriptures'. History and African Studies Seminar Series University of Natal 24, 1-30.

. 1999. 'Carl Faye's Transcript of Isaiah Shembe's Testimony of his Early Life and Calling'. Journal of Religion in Africa 29.3, 261-265.

Papini, R. and I. Hexham (eds.). 2002. The Catechism of the Nazarites and Related Writings. Lewiston: Edwin Mellen Press.

Parkes, M. B. 1999. 'Reading, Copying and Interpreting a Text in the Early Middle Ages'. In G. Cavallo and R. Chartier (eds.), A History of Reading in the West. London: Blackwell, 90-102.

Peel, John. 2000. Religious Encounter and the Making of the Yoruba. Indianapolis: Indiana University Press.

Peterson, Derek. 2004. Creative Writing: Translation, Bookkeeping and the Work of the Imagination in Colonial Kenya. Portsmouth, NH: Heinemann.

- 2006. 'Casting Characters: Autobiography and Political Imagination in Central Kenya'. Research in African Literatures 37.3, 176-192.

Posel, Deborah. 2001. 'Race as Common Sense: Racial Classification in 20th Century South Africa'. African Studies Review 44.2, 87-113.

Rich, Paul. 1995. 'Albert Luthuli and the American Board Mission in South Africa'. In Henry Bredecamp and Robert Ross (eds.), Missions and Christianity in South African History. Johannesburg: Witwatersrand University Press.

Roberts, Esther. 1936. Shembe: The Man and his Work. MA thesis, University of Witwatersrand.

Schlosser, Katesa. 1958. Eingeborenenkirchen in Sud-und Sudwestafrika. Kiel: Kommissionnsverlag Walter G. Muhlau.

Shembe, Johannes Galilee. 1940. IziHlabelelo zamaNazaretha. Durban: Universal Printing Works.

Sundkler, Bengt. 1948. Bantu Prophets in South Africa. London: Lutterworth Press. 1976. Zulu Zion and Some Swazi Zionists. Oxford: Oxford University Press.

Thornton, Robert. 1983. 'Narrative Ethnography in Africa, 1850-1920: The Creation and Capture of an Appropriate Domain for Anthropology'. Man 18, 502-520.

Tishken, Joel. 2006. 'Whose Nazareth Baptist Church? Prophecy, Power and Schism in South Africa'. Nova Religio: The Journal of Alternative and Emergent Religions 9.4, 79-97. 
Tshehla, Sam. 2003. 'Translation and the Vernacular Bible in the Debate between my "Traditional" and Academic Worldviews'. In Draper (ed.), Orality, Literacy and Colonialism in Southern Africa. Pietermaritzburg: University of KwaZulu-Natal Press.

Warner, Michael. 1992. 'The mass public and the mass subject'. In Craig Calhoun (ed.), Habermas and the Public Sphere. Cambridge, MA: MIT Press, 377-401.

Wells, Nellie. 1934. Shembe: Notes for Film. Typescript p7, Durban Local History Museums, Durban.

West, Gerald. 2006. 'Configuring the Female Body in Ibandla lamaNazaretha: Isaiah Shembe and Jephthah's Daughter'. Unpublished manuscript.

West, Martin. 1975. Bishops and Prophets in a Black City. London: R. Collins.

\section{Other Sources}

\section{Interviews, Poems, and Sermons}

Gogo MaDhlomo sermon, November 1993.

eMzimoya Meeting, Morning Sermon, Msinga, 6 September 2008.

Interview with Vukile Shembe, Ekuphakameni, 20 September 2008.

Interview with Bongiwe Mchunu, KwaZulu-Natal, 25 June 2008.

Masinga, Themba. 2008. Babonani abalandela uShembe? (CD recording, privately produced).

\section{Archives, Commissions, and Newspapers}

'Three Notebooks in Zulu, the Third Containing a Collection of Hymns and Other Item', School of Oriental and African Studies, Ms/380453.

Durban Local History Museums Collection 98/655.

Durban Local History Museums Collection 00/4583.

CAD (Central Archive Depot), GG 1550 50/825.

Central Archives Depot (SAB), Secretary for Native Affairs, NTS, Correspondence, 1917 1962.

The Native Churches Commission, Union Government 39, 1925.

Truth and Reconciliation Commission. 'Ibandla lamaNazaretha, Represented by M. P. Mpanza', 18 November 1999.

Natal Witness.

Sunday Tribune.

\section{Notes}

1. My thanks to the editor and anonymous readers of $J R A$ for their comments on earlier drafts. I am grateful for the financial support of Trinity College, Cambridge, the Smuts Fund , and research grants from the Faculties of Theology and History of the University of Cambride in enabling the research for this article.

2. Hexham and Oosthuizen (eds.), Story of Isaiah Shembe, 211.

3. For an outline of Isaiah Shembe's career, see Dube, UShembe; Vilakazi, Shembe. 
4. Gunner, Man of Heaven, 22-34; Gunner, 'The Word, the Book and the Zulu Church of Nazareth'; Gunner, 'Keeping a Diary of Visions'; Gunner, 'Dislocation, Memory and Modernity'; Muller, 'Making the Book'; Muller, 'Written into the Book of Life', 3-14; Hexham and Oosthuizen, The Story of Isaiah Shembe; Hexham and Oosthuizen, Acts of the Nazarites; Hexham and Oosthuizen, Continuing Story of the Sun and the Moon; Papini and Hexham, Catechism of the Nazarites; Papini, 'A Bilingual Publication Project for the Shembe Protoscripture', 1-30; West, 'Configuring the Female Body'.

5. Gunner, Man of Heaven, 28.

6. An important exception to this is Papini and Hexham, Catechism of the Nazarites, viii-xliii.

7. Although see Hexham and Oosthuizen, Continuing Story of the Sun and the Moon; Gunner, 'Keeping a Diary of Visions'.

8. See also Brown, 'The Hymns of Isaiah Shembe and the Church of the Nazarites'; Vilakazi, Shembe, 134-152; Oosthuizen, South African Messiah.

9. De Certeau, Practice of Everyday Life; McKenzie, Sociology of Texts; Barber, Anthropology of Texts; Chartier, Order of Books.

10. For a comparative discussion of how shifts in theatrical performance constituted different types of 'audiences', see Barber, 'Preliminary Notes on Audience in Africa', $347-$ 353.

11. Posel, 'Racial Classification in 20th Century South Africa', 87-113; Evans, Bureaucracy and Race. For broader reading on the social power of bureaucracy, see Habermas, Structural Transformation of the Public Sphere; Warner, 'The Mass Public and the Mass Subject', 377-401; Herzfeld, Social Production of Indifference.

12. Although Hofmeyr provides rich examples of how tropes of passbooks and passports featured prominently in the twentieth-century African Christian imagination. Hofmeyr, Portable Bunyan.

13. Chartier, Order of Books, ix-x.

14. La Hausse, Restless Identities, 100.

15. La Hausse, Restless Identities, 176, n. 31.

16. In the late nineteenth century his father, Mayekisa, was a labour tenant for an Afrikaans farmer in the Harrismith area. Papini, 'Carl Faye's Transcript', 261.

17. Gunner, Man of Heaven, 17-22.

18. Gunner, Man of Heaven, 17-22; Dube, UShembe, 25-26.

19. Sundkler, Zulu Zion, 187. Isaiah only learned how to read and write when he was about 40 .

20. Hexham and Oosthuizen, Story of Isaiah Shembe, 33.

21. Hexham and Oosthuizen, Story of Isaiah Shembe, 33.

22. La Hausse, Restless Identities, 103.

23. The 1883 AZM translation was the most likely Bible to have been used by Shembe. Up until 1924 it was the only complete Zulu Bible available, and an updated version of it is still used today by contemporary Nazaretha. Hermanson, 'Bible Translation in South Africa', 6-17; Muller, 'Making the Book', 93.

24. Papini, 'Carl Faye's Transcript', 263.

25. Tshehla, 'Translation and the Vernacular Bible', 184.

26. Papini, 'Carl Faye's Transcript', 267-269; Hexham and Oosthuizen (eds.), Story of Isaiah Shembe, 10-13.

27. Hexham and Oosthuizen (eds.), Story of Isaiah Shembe, 26-28.

28. Roberts, Shembe, 58. 
29. Sundkler, Zulu Zion, 186.

30. Gunner, Man of Heaven, 111-113. The First Words of Advice of Shembe at Roosboom, August 26, 1933.

31. Roberts, Shembe, 54.

32. SAB, NTS 1431, 24/214, Minutes of 1932 Native Economic Commission, 6544.

33. Wells, 'Shembe', 2.

34. In a 1933 sermon Isaiah cautioned his listeners 'to clearly understand the word (izwi) that was written for you in the Book of the amaNazaretha, in the Prayer of KwaZulu, the 21st verse'. Hexham, Scriptures of the amaNazaretha, 42. The Second Advice.

35. Hofmeyr, Portable Bunyan, 17.

36. Wells, 'Shembe', 2.

37. A 1918 American Zulu Mission report for their girls' school in Inanda, Inanda Seminary mentions one 'Shembeite' girl who had recently become a pupil. Could this be Sangiwe Magwaza? NAB (ABM A/3/42 Inanda Seminary Report 1918). Gunner, 'Power House, Prison House', 205.

38. Gunner, 'Diary of Visions', 49.

39. Gunner, Man of Heaven, 157. Meshack Hadebe's Testimony. 'The Lord of the Nazaretha, Shembe, sent his child Amos Shembe to hear [i.e., to write down] the story from Meshack himself'.

40. Hexham and Oosthuizen, Acts of the Nazarites, 285. Petros Dhlomo.

41. Ibid.

42. Gunner, 'Diary of Visions', 49.

43. Gunner, 'Power House, Prison House', 205.

44. Barber has suggested that this may be akin to the dialogue between oral performer and a responsive audience in other, secular, regional performance genres. Barber, Anthropology of Texts, 146

45. Tape cassette recording of Gogo MaDhlomo's Sabbath-day sermon, November 1993, Mooi River. Property of Khumalo family.

46. For example, the occasion when an amanuensis recorded Isaiah's narration of his autobiography to his gathered followers at Ekuphakameni in 1926. Papini and Hexham, Catechism of the Nazarites, 182.

47. Breckenridge, 'Reasons for Writing', 143.

48. In 1940 Isaiah's son and successor, Johannes Galilee, issued a centrally printed church hymnal—or iziblabelelo — undercutting the need for handwritten copies. Shembe, IziHlabelelo zamaNazaretha.

49. Gunner, 'Keeping a Diary of Visions', 160,

50. Gogo MaDlomo's sermon, November 1993.

51. Hexham and Oosthuizen, Story of Isaiah Shembe, 224.

52. Landau, Realm of the Word, 144. For a Yoruba example of books as magical objects, see Peel, Religious Encounter and the Making of the Yoruba, 223.

53. This visual decoration is evident in the three photocopies of Nazaretha scribes' notebooks kept in the library of the School of Oriental and African Studies ('Three notebooks in Zulu, the third containing a collection of hymns and other item').

54. Gunner, Man of Heaven, 203, footnote 28.

55. Interview with Bongi Mchunu, 25 June 2008, Mooi River.

56. Esther Roberts was present at Shembe's funeral and provided a detailed account in her thesis. Roberts, Shembe, 196; Gunner, 'Power House, Prison House', 186.

57. Roberts, Shembe, 97. By the early 1960s Dhlomo had typed up some of these para- 
bles and circulated them as a photocopied booklet for devotional use among church members.

58. Roberts, Shembe, 97.

59. Roberts, Shembe, 97.

60. Hexham and Oosthuizen, Story of Isaiah Shembe, 193.

61. Shembe, Izihlabelelo zaManazaretha, v.

62. One of Isaiah's earliest missionary outposts was in the southern Mpondo region. By the 1930s he had congregations in the very far north in Nongoma, as well as in the very northwest part of Natal in the Msinga district.

63. Interview with Bongi Mchunu, 25 June 2008, Mooi River.

64. Hexham and Oosthuizen, Acts of the Nazarites, 31; Gunner, 'Power House, Prison House', 217; Papini and Hexham, Catechism of the Nazarites, 23.

65. Interview with Bongi Mchunu, 25 June 2008, Mooi River.

66. Some church accounts also mention Ministers Amos Mzobe and Hadebe being sent with Mnqayi to the area. Interview with Bongi Mchunu. Mnqayi seems to have been preaching in emaChunwini and surrounding areas as early as 1920-1921. Hexham and Oosthuizen, Acts of the Nazarites, 155.

67. Gogo MaDhlomo's 1993 sermon refers to Mnqayi's 'church'. Isaiah visited emaChunwini in an unsuccessful attempt to convince the breakaway Minister Mnqayi to return to the fold. Hexham and Oosthuizen, Acts of the Nazarites, 159; Andrina Hlanguza, 173-176. Philip Ngubane.

68. Hexham, Scriptures of the amaNazaretha, 75.

69. Hexham, Scriptures of the amaNazaretha. 71.

70. Gunner, Man of Heaven, 77. 'Concerning Petros Mnqayi-1932'. In a scribed letter to 'those who love the Nkosi in the land South of the Tugela, at Umhlali', Isaiah expressed his wish that his written address might not 'speak words out of my own mouth, Lord (Nkosi)! Be you with my mouth, Lord! (Nkosi)'. Hexham, Scriptures of the amaNazaretha, 90.

71. Hexham, Scriptures of the amaNazaretha, 58. The Words Concerning a Prisoner: They were written by the Servant of the Nkosi at Bellehem Juda Letter to Bangizwe Mhlongo.

72. Throughout this paragraph, the italicized form of 'words' is my emphasis.

73. Ibid.

74. Gunner, Man of Heaven, 106-107.

75. Hexham, Scriptures of the amaNazaretha, 74.

76. Gunner, Man of Heaven, 91. The Thembalimbe Affair.

77. Hexham, Scriptures of the amaNazaretha, 93.

78. Hexham, Scriptures of the amaNazaretha, 74-75.

79. Hexham, Scriptures of the amaNazaretha, 71. At Nhlangakazi, 27 January 1934.

80. Sundkler, Bantu Prophets, 160; Roberts, Shembe, 115.

81. Peterson, 'Casting Characters', 182.

82. Hexham and Oosthuizen, Story of Isaiah Shembe, 88.

83. Hexham and Oosthuizen, Acts of the Nazarites, 297.

84. Hexham and Oosthuizen, Story of Isaiah Shembe, 219; Hexham and Oosthuizen, Continuing Story of the Sun and the Moon, 60, 72, 153, 177; Hexham and Papini, Catechism of the Nazarites, 99.

85. Gunner, Man of Heaven, 77. 'If you listen to what I say to you today: 'Uma uwalalela lawa mazwi engizowakhuluma kuwe namhlanje’. 
86. Hexham, Scriptures of the amaNazaretha, 100.

87. Hexham, Scriptures of the amaNazaretha, 90. The Letter of the Servant of the Sorrow of Nkulunkulu: Shembe.

88. Hexham, Scriptures of the amaNazaretha, 61-65. The Prayer of Shembe in Remembrance of His Nation.

89. Hexham, Scriptures of the amaNazaretha, 40-42. Shembe's First Advice at Roosboom, 26 August 1933.

90. Gunner, Man of Heaven, 76-77. Hexham, Scriptures of the amaNazaretha, 18-20.

91. Xhosa praise poet David Manisi similarly recognized print media's ability to create enduring records. Lenta, 'Thembu Praise Poet David Manisi', 45-64.

92. See Peterson, Creative Writing 25, 117-137, for a discussion of how Gikuyu innovators of the 1930s appropriated and transformed the syntax of the colonial state, arguing that they were hence well-equipped to take over governmental power.

93. SAB, NTS 1431, 24/214 DG Shepstone to CNC, 27 October 1931; Native Commissioner Mtunzini to CNC, 23 August 1939; CNC to Secretary for Native Affairs, 25 January 1940.

94. Hexham and Papini, Catechism of the Nazarites, 108.

95. Gunner, Man of Heaven, 37.

96. Masinga, Babonani abalandela uShembe?

97. Schlosser, Eingeborenenkirchen in Sud-und Sudwestafrika, 221.

98. Burchell, 'Adams College, Natal', 151.

99. Schlosser, Eingeborenenkirchen in Sud-und Sudwestafrika, 221.

100. De Certeau, Practice of Everyday Life, 176.

101. Sundkler, Zulu Zion, 186-187.

102. Burchell, 'Adams College', 153.

103. Ibid., 154 .

104. Rich, 'American Board Mission', 194.

105. Hexham and Oosthuizen, Continuing Story of the Sun and the Moon, 103. Josiah Mthethwa.

106. Benedict Anderson makes this point: 'A characteristic feature of the state was infinite reproducibility, a reproducibility made technically possible by print and photography'. Anderson, Imagined Communities, 182.

107. Houghton, The Tomlinson Report, 65-66.

108. Sundkler, Bantu Prophets, 303.

109. This type of description is evident as early as the 1920s. In 1920 the prime minister described African-led churches as the 'many unstable and irresponsible communities of which the natives are so prolific'. Claasen, 'Independents Made Dependent', 25.

110. (SAB), NTS 1431, 24/214 AH Astrup to Magistrate and Native Commissioner, Hlabisa, 21 September 1942. The state's fear of Independent churches was also fed by the events of 1921, in the form of the 'Bulhoek Massacre' in which hundreds of followers of the Eastern Cape prophet, Enoch Mgijima, violently clashed with the police. The Native Churches Commission, 7-17.

111. Sundkler, Bantu Prophets, 77; Claasen, 'Independents Made Dependent', 20-21.

112. SAB, NTS 1431, 24/214 Chief Native Commissioner to Secretary for Native Affairs, 25 January 1940. The temples were Judea, Gibizisila, and Velabahleka.

113. Until 1963 when the mechanism of 'government recognition' was indefinitely halted. Oosthuizen, 'A History of Persecution', 1110.

114. Claasen, 'Independents made Dependent', 19-20. 
115. SAB, NTS 1431, 24/214 Chief Native Commissioner (CNC) to Secretary for Native Affairs (SNA) 7 June 1946; CNC to SNA 8 September 1950.

116. Sundkler, Zulu Zion and Some Swazi Zionists, 287.

117. Hexham and Oosthuizen, Continuing Story of the Sun and the Moon, 114. Mzikayise Khuluse.

118. Oosthuizen, 'Nazareth Baptist Church of Shembe', 8; Natal Witness, 2 September 1982.

119. Oosthuizen, 'Succession Conflict', 33.

120. SAB, NTS 1431, 24/214 Chief Native Commissioner to Secretary for Native Affairs, 7 June 1946.

121. For example, the African Methodist Episcopal Church and the Bantu Presbyterian Church both had hymnals. Sundkler, Bantu Prophets, 76.

122. The church only gained recognition in the 1980s after it aligned itself with a larger union of African Independent Churches, 'The Reformed Independent Churches Association' (RICA). Sundkler, Zulu Zion and Some Swazi Zionists, 289. Mpanza, TRC Testimony.

123. Oosthuizen, 'Succession Conflict', 7-9.

124. In general, early twentieth-century Independent churches were characterized by the strong influence of women, and claims of female mediums to channel the spirit of a deceased founder or even the Holy Spirit were not unusual. Sundkler, Bantu Prophets, 139-144; West, Bishops and Prophets in a Black City, 50-52.

125. Interview with Bongiwe Mchunu, 25 June 2008.

126. The Sunday Tribune 24 July 1966 noted that 'Johannes Galilee, the educated charming present leader of the Nazarites is collecting testimonies regarding his father'.

127. Hexham and Papini, Catechism of the Nazarites, xxv.

128. Gunner, 'Power House, Prison House', 207.

129. Sundkler, Zulu Zion, 175.

130. Sundkler, Zulu Zion, 175.

131. Hexham and Oosthuizen, Story of Isaiah Shembe, xv.

132. Johannes's Iziblabelelo zaManazaretha (Hymnal of the Nazaretha) was first published in 1940

133. Muller and Mthethwa, Hymns of the Nazaretha, ii.

134. Dube, UShembe (published in 1936).

135. Hexham and Oosthuizen, Story of Isaiah Shembe, xii.

136. The Mngcwabo was translated in 2002 as part of a larger project undertaken and funded by the NERMIC unit at the University of Zululand. The text is found in Papini and Hexham, Catechism of the Nazarites, xvii.

137. The point is made by Papini and Hexham, Catechism of the Nazarites, xxxiv.

138. Hexham and Oosthuizen, Continuing Story of the Sun and the Moon, 199. Alfred Ndlangisa.

139. For an example of these, see Schlosser, Eingeborenenkirche, in Sud-und Sudwestafrika, 245.

140. Interview with Bongi Mchunu, 25 June 2008.

141. Chartier, Order of Books, viii.

142. K. Barber, 'Audiences in Africa', 348-349.

143. Oosthuizen, South African Messiah, 1.

144. Oosthuizen, 'Succession Conflict', 33.

145. Parkes, 'Reading, Copying and Interpreting', 92-93. 
146. Throughout 2006, 2008, and 2009, I observed similar use of the hymnal during Nazaretha services. Believers would hold the hymnal during the service but the prayer liturgies and hymns were so familiar that the page did not actually have to be read by the book's owner.

147. Gogo MaDhlomo Sermon, 1993.

148. eMzimoya Meeting, Morning Sermon, Msinga, 6 September 2008.

149. Hexham and Oosthuizen, Continuing Story of the Sun and the Moon, 135-136. Mshiseni Malembe.

150. Durban Local History Museums Collection 98/655.

151. Becken, 'On The Holy Mountain', 142.

152. The earliest tape recording I have evidence of is a recording made of Johannes preaching in July 1968 at Ekuphakameni. Possession of Nkosinathi Sithole.

153. Papini and Hexham, Catechism of the Nazarites, 128. 'The Revived Law of Johannes Galilee Shembe’.

154. Hirschkind, 'Ethics of Listening', 624. 